\title{
Pro-Efficiency Model of the Organizational Climate
}

Anna WZIĄTEK-STAŚKO ${ }^{1}$ and Olena KRAWCZYK-ANTONIUK ${ }^{2}$

\author{
${ }^{1}$ Faculty of Management and Social Communication, Institute of Economics, Finance and \\ Management; Department of Human Resources Management; Jagiellonian University in Kraków, \\ Łojasiewicza, Kraków, Poland \\ ${ }^{2}$ Businesswoman, Law-Administration-Taxes, Gorzołki Gliwice, Poland
}

Correspondence should be adressed to: Anna WZIĄTEK-STAŚKO; anna.wziatek-stasko@uj.edu.pl

Received date: 1 October 2020; Accepted date: 22 January 2021; Published date: 8 February 2021

Academic Editor: Marta Młokosiewicz

Copyright (C) 2021. Anna WZIĄTEK-STAŚKO and Olena KRAWCZYK-ANTONIUK.Distributed under Creative Commons Attribution 4.0 International CC-BY 4.0

\begin{abstract}
Work is the main part of an adult's life. It significantly influences people's ideas and views, shapes their attitudes and life aspirations. For some, it becomes just a means of livelihood. For others, it is a way of expressing and making their personality real. Work shapes the way people perceive, think and behave. Its place in the employee's value system has a significant impact on their attitude: activity, mediocrity, passivity or negation. The leading determinant of the way people perceive the workplace is the image of the organizational climate that exists in each organization. The main goal of the article is to present the author's concept of a pro-efficiency model of the organizational climate in theoretical terms, as well as its practical approach. The key added value of the article is the indication of the components of the organizational climate that are particularly important in the process of raising the level of selected parameters for assessing the organizational effectiveness of enterprises, taking into account the opinions of people employed in blue-collar positions, non-manual workers without subordinate employees and managers. The results of the research allowed identifying the different preferences of the respondents, taking into account the adopted moderating variable.
\end{abstract}

Keywords: organisational climate, organisational climate model, organisational effectiveness, effectiveness-supporting organisational climate model.

Cite this Article as: Anna WZIĄTEK-STAŚKO and Olena KRAWCZYK-ANTONIUK (2021)," Pro-Efficiency Model of the Organizational Climate", The Journal of Organizational Management Studies, Vol. 2021 (2021), Article ID 216555, DOI: 10.5171/2021.216555 


\section{Introduction}

While the concept of "the organisational climate" is very popular in the world of science as a research category, it seems that it is still not receiving sufficient attention from managers in enterprises and their staff. It appears that it is not sufficiently understood as a concept and, consequently, its exploration is based largely on intuition. It may be so because its operationalisation is more difficult than one may expect; however, it is important and implies certain consequences.

From the grammar point of view, the term "organisational climate" is a metaphorical adjective, whose first element is ambiguous in nature. The noun "climate" may refer both to rooms, buildings, interpersonal relations as well as to meteorological properties. What these examples have in common is that, in each such example, a man feels the climate and the concept of the climate usually refers to people's adaptation to the existing conditions. In the literature, the term "the organisational climate" is sometimes replaced with the term "the atmosphere" which suggests that, to some extent, these terms are meteorology-related (Wudarzewski, 2013). L. von Rosenstiel i F. Bögel (1992) pointed out directly that "in the congitive sense, the organisational climate is similar to the meteorological climate since (...) we tend to describe interpersonal relations as warm, cold or that a storm is brewing". Accordingly, in spite of the meteorological roots of the term of the "organisational climate", at present, the term seems also firmly attached to the management sciences. It is of particular importance in the context of building a strong organisational culture, of which it is an element, raising the level of motivation and engagement of the staff, its creativity, openness to changes and risk propensity which, eventually, translates into increasing (or reducing) the level of effectiveness and economic and organisational efficiency of enterprises. "The rules of conduct, standards and values arising from the organisational culture determine both the effectiveness for formulating the company's strategy, effectiveness of change management processes as well as the effectiveness of motivational systems" (Altaf, 2011; also see: Hulkko-Nyman, Sarti, Hakonen, Sweins, 2014; Jacobs, Renard, Snelgar, 2014; Harrington, Voehl, 2015; Aybas, Cevat Acar, 2017; Yongxing, Hongfei, Baoguo, Lei, 2017). In light of the above, it is of utmost importance to have complete understanding of the essence and the role of the organisational climate as wel as the mechanism of its impact on the effectiveness of the staff and, consequently, of the entire organisation.

This article presents the results of the research conducted in a search for a very important question: does a type of a position occupied by an employee (white collar, blue collar without subordinate employees, a managerial position) determine the structure of the effectiveness-supporting organisational climate model?

The essence and the role of the organisational climate

In many organisations, the problem is that managers ignore or even completely conceal the importance of the organisational climate in the process of effective people management. What is more, many of them do not see the relationship or misinterpret the relationship between the organisational climate and the organisational effectiveness of the company.

The organisational climate is an ambiguous concept and its interpretation may vary. Over the years, many attempts have been made to operationalise it. The organisational climate:

- $\quad$ is the dominant way of perception in the organisation and the overall emotional responses of employees to their own work environment (Aarons, Sawitzky, 2006),

- $\quad$ it is the atmosphere prevailing in the organisation which affects the people (Dessler, Turner, 1992),

- these are the features distinguishing an organisation from other 
organisations in terms of the behaviour of other people in the organisation, which are relatively unchanged over time (Forehand, Gilmer, 1964),

- $\quad$ is a normative structure of attitudes and standards of behaviour, which serves as the basis for interpreting the situation and taking actions that constitute a source of pressure on the direction of activity (Gregopoulos, 1965),

- is a subjectively perceived set of features of an organisation, dependent on external and internal factors, which affect the behaviour of employees inside the organisation (Łochnicka, 2016).

The organisational climate means the relationships between the employee and colleagues and line managers, in particular the feeling of a friendly atmosphere in the work group and the ability to count on the help of both colleagues and line managers (Baruk, 2014); it is also the main factor shaping organisational behaviour of employees, resulting from the content of social relations including the conditions of the institution's functioning - a formal power structure, type of technology, requirements for organisations, motives aspirations and interests of employees and teams of employees (Wudarzewski, 2016). The organisational climate is a manifestation of the organisational culture (Dabic, Laznjak, Smallbone, Svarc, 2018).

The wealth of views on the organisational climate does not make it easier to understand its essence. Taking a synthetic look at the organisational climate, one may conclude that some researchers perceive it as a way of perception and all emotional reactions, some see it as a factor shaping organisational behaviour of employees, and others as a normative structure of attitudes and behaviours. A different view allows us to see in the organisational climate a set of features characterising an organisation, including its standards, organisational policy, the internal work environment, patterns of behavior, attitudes, feelings, habits, interpersonal relationships, a set of measurable properties of the work environment.

Although a precise definition of the "orgnisational climate" concept is impossible to formulate, the importance of its role in an organisation should be emphasised as the organisational climate is responsible for the quality of the work environment, for the quality of interpersonal communication and for possible conflicts or their lack. The right organisational climate can increase employee satisfaction with work and, as a result, the level of their motivation, have a positive impact on their health (both mental and possible psychosomatic ailments) and well-being, which ultimately translates into the results of the entire organisation Badura, 2016).

The consequence of failing to meet the expectations of employees as to providing them with the organisational climate they desire may be a decrease in their organisational commitment, an increase in morbidity, a less enthusiastic approach to work than expected, lack of job satisfaction, which may be reflected in their critical assessment of the entire organisation, externalizsed in a more or less official way. Permanent dissatisfaction of employees is a factor that signals to the top management that there are dysfunctions in the management process and that the manager lacks sufficient managerial competences.

Extensive literature studies indicate that the structure of the organisational climate can be built by an immeasurably wide variety of components that interact with each other. The subject was taken up by many authors (e.g., Abendroth, den Dulk, 2011; Avgar, Kolins-Givan, Liu, 2011; McDonald, Townsend, Wharton, 2013; Davidson, Manning, Timo, Ryder, 2001; Kundu, 2007, Wudarzewski, 2013; Bratnicki, Wyciślak, 1980; Wajszczak, 2000 , etc.). The following parameters are the most frequently mentioned in the world literature, repeated in the opinion of most authors over the last 70 years:

- friendly interpersonal relations (friendliness and affection),

- relations between a manager and an employee, 
- $\quad$ mutual trust,

- transparency of information,

- efficiency of communication,

- support from one's line manager (supportive style of management),

- challenges (including professional challenges),

- motiviation for work,

- $\quad$ structure (complexity),

- $\quad$ transparency of information.

Appreciating the many years of scientific achievements of dozens of researchers around the world, as well as using their extensive experience related to the exploration of issues related to the organisational climate and its modelling, the authors of this study have developed a proprietary model, including components of particular importance in the process of optimizing the level of organisational effectiveness:

A1. Equal treatment of employees; A2A. The level of trust in the information coming from the line manager; A2B. The level of trust in the information coming from colleagues;

A3A. The remuneration system used in the organisation;

A3B. The remuneration system used in the department/team;

A4A. Interpersonal relations in the organisation;

A4B. Interpersonal relations in the department/team;

A5A. Efficient communication in the organisation;

A5B. Efficient communication in the department/team;

A6. Commitment to the organisation.

\section{The essence of the organisational effectiveness}

The category of "effectiveness" is an equally popular and ambiguous notion as is "the organisational climate". Despite many attempts, it has not been unequivocally defined in such a way that this definition would meet with universal acceptance. As Blaik observes (2015), sometimes one may think that subsequent, not always in-depth, attempts to define and identify the essence of efficiency in various areas of management (economy and management), contrary to the assumed intentions, rather contribute to deepening the aforementioned ambiguity and terminological confusion, especially in the context of the already existing multitude of definitions. Pyszka (2015) believes that, within the scope of the issue of effectiveness, the authors follow the footsteps of effects, i.e., the results of action, usually identified with economic effects. However, it is increasingly suggested to analyse effectiveness in a wider context. While discussing effectiveness, the above-mentioned author raises the importance and the need to attempt at answering three important questions:

- In what way definition of effectiveness may affect its measurement?

- Does a broader non-economic approach to efficiency enable better identification of the positive effects of an organisation's operation?

- How does the change in the dynamics of effectiveness affect the assessment of the purposefulness of an action?

Skrzypek (2007) claims that, in management sciences, efficiency is related to such concepts as efficiency, effectiveness, productivity, profitability, rationality, but its nature overrides them. Ziębicki (2014) emphasises that, in the literature, it is in two meanings: as economic efficiency and as organisational efficiency, with the proviso that economic efficiency is presented as one of the manifestations of organisational effectiveness. As a rule, economic efficiency is defined as the ratio of results to inputs, while organisational efficiency is defined by means of multidimensional criteria. The criteria encompass different categories of results and attributes of an organisation. This domain was researched by many scientists (e.g., Cameron, 1986; Goodman, Pennings, 1977; Lawless, 1972; Lewin, Minton, 1986; Price, 2008; Steers, 1975, etc.). Bielski (2002) emphasises that "there is no single best criterion for assessing effectiveness, and their selection is subjective and is made under the influence of the values, preferences and interests of 
the entity making the assessment". Similarly, Kondalkar (2010) observes some difficulties in operationalising the concept, claiming that "organisational effectiveness is a complex phenomenon and is mostly based on the adopted strategy adapted to the needs of the development of individual individuals and teams (...) this perception of efficiency is related to the personal development of employees, who thus demonstrate a high level of motivation and emotional balance". The above view allows for a relatively free interpretation and opens the possibility of creating original solutions in the selection of measures for assessing the level of organisational effectiveness, which was done by the authors of this study.

Based on the analysis of the literature on the subject, six measures of organisational effectiveness have been identified, most often indicated as the key measures according to an international group of researchers, such as:

B1A. The degree of achieving organisation's goals; B1B. The degree of achieving employee's goals;

B2A. Personnel development level shaped by the influence exerted by the line manager;

B2B. The level of staff development shaped by colleagues;

B3. Fast adaptability to changes (by the organisation);
B4. The degree of the employees' ability to deliver tasks in compliance with the rules (standards) of the organisation;

B5A. Individual performance (effectiveness) of employees assessed by their line manager;

B5B. Individual performance (effectiveness) of employees according to their selfassessment;

B6. Convergence of employee's values and values promoted in the organisation.

Adopting the proprietary definition of "the efficiency-supporting model of the organisational climate" reading: "the efficiency-supporting model of the organisational climate means the construction of an ideal organisational reality, constituting a set of subjectively perceived by all employees its characteristics, enabling the study of the structure of this reality, the relationship between its elements and factors affecting it, which guarantees that the organisation's performance is optimal for the investment made in the organisation and performance", and taking into account the above-identified organisational climate components (A1-A6) and measures to assess organisational effectiveness (B1B6), an attempt was made to create a model after the pattern presented in Fig. 1.

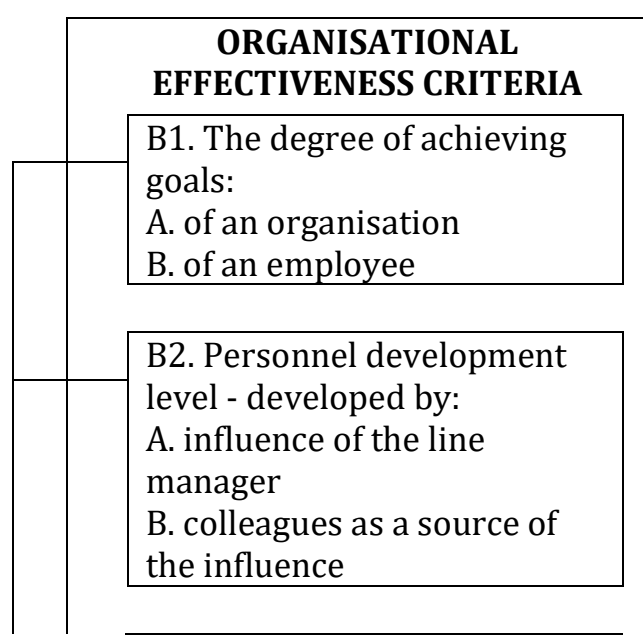




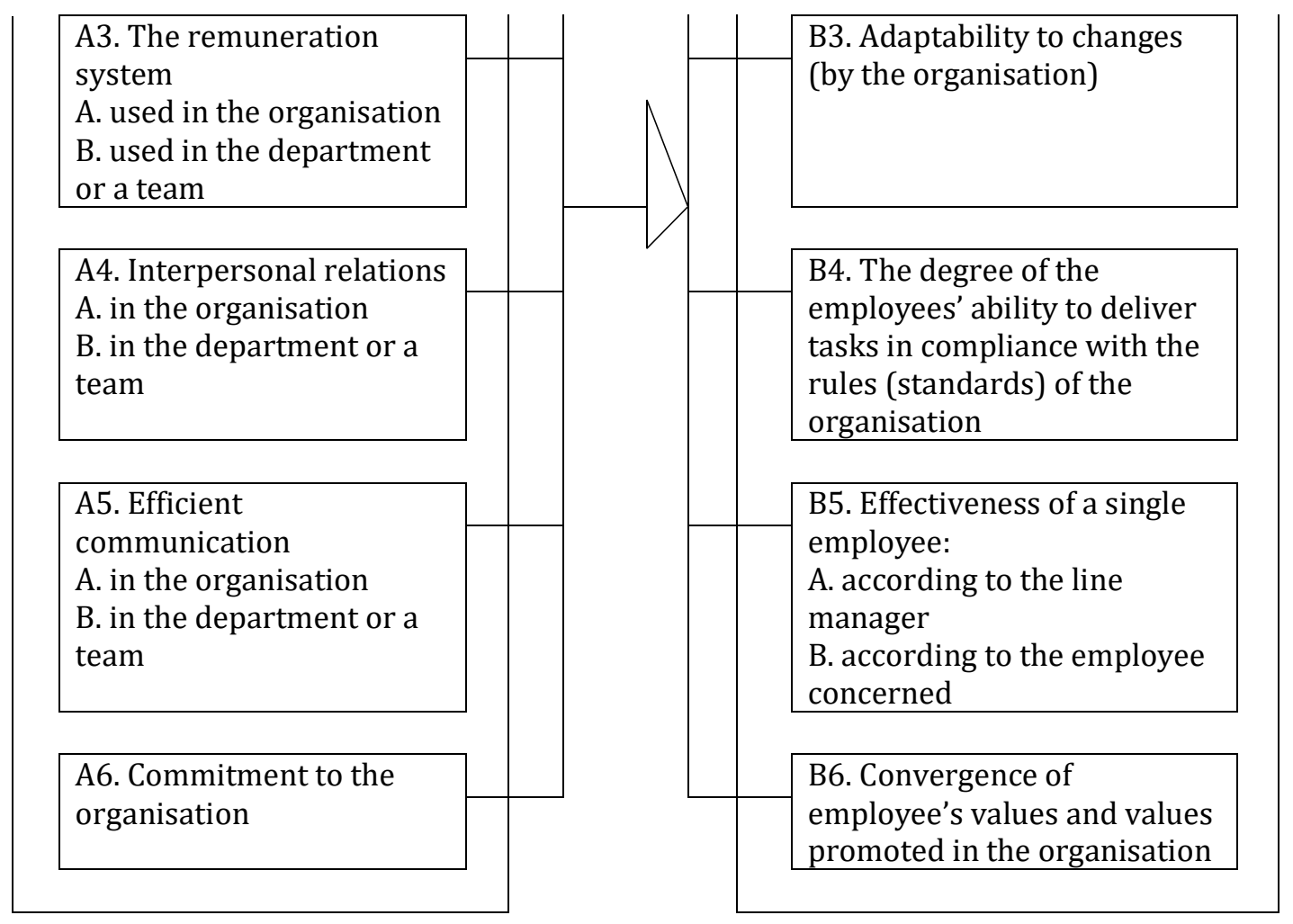

Figure 1: Effectiveness-supporting organisational climate model - theory

Source: Own analyses and studies

\section{Research Methodology}

In the research process, a proprietary questionnaire was used, its structure based on the identified variables: independent variables (A1-A6) and dependent variables (B1-B6). In the questionnaires, a 5-point Likert scale (1-5) was used, which is an estimative, dependency-displaying, onedimensional scale while classified too a group of complex scales used to measure attitudes. The empirical research was run on a representative sample, where the type of job/position (blue collar, white collar, non-managerial without subordinate employees, managerial) was used as a moderating variable. The following assumptions were made when determining the optimal size of the sample:

- The analysis based on a regressive scheme to allow for analysing many organisational climate components (predictors) in a single statistical mode,
- The size of the sample should make it possible to run analyses for all ten organisational climate components (predictors),

- The value of the strength of the statistical reasoning was 0.80 ,

- A conventional threshold of 0.05 was used as the statistical significance threshold,

- A statistical model which allows for detecting even slight outcomes of 0.02 of $\mathrm{f}^{2}$ Cohen's.

The research was conducted by using an Internet questionnaire and by direct questionnaire research among respondents. The research sample consisted of 1,348 respondents, out of which 1,266 properly filled out questionnaires, were selected and eventually used in the process of the analysis. $G^{*} 3 \cdot 1.9 .2$. software was used for calculations. See Table 1 for respondents' structure by chosen criteria. 
Table 1: Respondents' structure by different criteria

\begin{tabular}{|c|c|c|c|c|}
\hline No. & & Criterion & $\mathbf{N}$ & $\%$ \\
\hline \multirow{2}{*}{1} & \multirow{2}{*}{ Sex } & Woman & 740 & $58 \%$ \\
\hline & & Men & 526 & $42 \%$ \\
\hline \multirow{5}{*}{2} & \multirow{5}{*}{ Age } & Up to 25 years & 486 & $38 \%$ \\
\hline & & Age 26-35 & 362 & $29 \%$ \\
\hline & & Age $36-45$ & 219 & $17 \%$ \\
\hline & & Age 46-55 & 119 & $9 \%$ \\
\hline & & 55 and more & 80 & $6 \%$ \\
\hline \multirow{7}{*}{3} & \multirow{7}{*}{ Education } & Elementary & 8 & $1 \%$ \\
\hline & & Lower secondary & 10 & $1 \%$ \\
\hline & & Vocational & 63 & $5 \%$ \\
\hline & & Secondary & 610 & $48 \%$ \\
\hline & & Upper secondary (eng., B.A.) & 282 & $22 \%$ \\
\hline & & M.A. or equivalent & 258 & $20 \%$ \\
\hline & & Academic title & 35 & $3 \%$ \\
\hline \multirow{6}{*}{4} & \multirow{6}{*}{ Industry } & Commerce & 169 & $13 \%$ \\
\hline & & Industry & 239 & $19 \%$ \\
\hline & & Construction & 41 & $3 \%$ \\
\hline & & Agriculture & 4 & $0 \%$ \\
\hline & & Services & 452 & $36 \%$ \\
\hline & & Other sectors & 361 & $29 \%$ \\
\hline \multirow{4}{*}{5} & \multirow{4}{*}{$\begin{array}{c}\text { No. of employees at } \\
\text { respondents' } \\
\text { employers }\end{array}$} & $2-9$ & 199 & $16 \%$ \\
\hline & & $10-49$ & 314 & $25 \%$ \\
\hline & & $50-249$ & 298 & $24 \%$ \\
\hline & & 250 and more & 455 & $36 \%$ \\
\hline \multirow{3}{*}{6} & \multirow{3}{*}{$\begin{array}{c}\text { Number of team } \\
\text { members }\end{array}$} & $2-5$ & 606 & $48 \%$ \\
\hline & & $6-15$ & 430 & $34 \%$ \\
\hline & & 16 and more & 230 & $18 \%$ \\
\hline \multirow{3}{*}{7} & \multirow{3}{*}{$\begin{array}{c}\text { Type of } \\
\text { job/position }\end{array}$} & Blue collar & 456 & $36 \%$ \\
\hline & & White collar, non-managerial & 531 & $42 \%$ \\
\hline & & Managerial & 279 & $22 \%$ \\
\hline \multirow{3}{*}{8} & \multirow{3}{*}{$\begin{array}{c}\text { Respondents' } \\
\text { organisation } \\
\text { ownership type }\end{array}$} & Public sector & 389 & $31 \%$ \\
\hline & & Private sector & 837 & $66 \%$ \\
\hline & & Third sector organisations (NGOs) & 40 & $3 \%$ \\
\hline \multirow{3}{*}{9} & \multirow{3}{*}{$\begin{array}{l}\text { Respondents' total } \\
\text { years of work } \\
\text { experience }\end{array}$} & $<12$ months & 131 & $10 \%$ \\
\hline & & From 1 to 5 years & 446 & $35 \%$ \\
\hline & & From 5 to 15 years & 356 & $28 \%$ \\
\hline
\end{tabular}




\begin{tabular}{|c|c|c|c|c|}
\hline No. & & Criterion & $\mathbf{N}$ & $\%$ \\
\hline & & $>15$ years & 333 & $26 \%$ \\
\hline \multirow{4}{*}{10} & \multirow{4}{*}{$\begin{array}{c}\text { Respondents' years } \\
\text { of work experience } \\
\text { at their current } \\
\text { employer }\end{array}$} & $<12$ months & 394 & $31 \%$ \\
\hline & & From 1 to 5 years & 526 & $42 \%$ \\
\hline & & From 5 to 15 years & 233 & $18 \%$ \\
\hline & & $>15$ years & 113 & $9 \%$ \\
\hline \multirow{4}{*}{11} & \multirow{4}{*}{$\begin{array}{l}\text { Respondents' years } \\
\text { of work at their } \\
\text { present position }\end{array}$} & $<12$ months & 433 & $34 \%$ \\
\hline & & From 1 to 5 years & 569 & $45 \%$ \\
\hline & & From 5 to 15 years & 197 & $16 \%$ \\
\hline & & $>15$ years & 67 & $5 \%$ \\
\hline
\end{tabular}

Source: Authors' own analyses and studies

Dependencies between pairs of the analysed variables i.e., each component of the organisational climate (A1-A6) and each organisational effectiveness ratio (B1B6) were analysed with $\rho$ Spearman rank correlation coefficient. The research results are presented in the tables 2 to 8 , where $\mathrm{p}$ represents the statistical significance i.e., defines the probability of a random result. If the probability is lower than 0.05 , the result is statistically significant. Fisher transformation values (z) complimented the list and were used to verify the statistical significance of the differences between the values of the correlation coefficients in the compared groups. In the tables 2 - 8, the values confirming that dependences between variables, of statistical significance, are presented in red.

\section{Research results}

The research process as a whole included:

- the respondents' assessment of selected components of the organisational climate (A1-A6), taking into account the type of job they occupy,

- the respondents' assessment of the level of selected parameters of organisational effectiveness, (B1-B6), taking into account the type of job they occupy,

- analysis of the correlation between all components of the organisational climate (A1-A6) and all criteria for the assessment of organisational effectiveness (B1-B6), taking into account the type of job position held by the respondents.
Due to the very extensive factual material that allowed the collection of the abovementioned stages of the research process, this article presents only the results that concerned the analysis of the correlation between both groups of parameters, including the type of job position, according to the specification below.

- Table 2 - Spearman rank correlation $\rho$ coefficients between the assessments of selected components of the organisational climate (A1-A6) and the assessments of the degree of achievement of the employee's goals (B1B),

- Table 3 - Spearman rank correlation coefficients between the assessments of selected components of the organisational climate (A1-A6) assessing the level of human resources development shaped by the influence of colleagues (B2B),

- Table 4 - Spearman rank correlation coefficients between the assessments of selected components of the organisational climate (A1-A6) and the assessments of the organisation's capacity to adapt rapidly to changes (B3),

- Table 5 - Spearman rank correlation coefficients between the assessments of selected components of the organisational climate (A1-A6) and the assessments of the degree of achievement of the employee's goals (B4),

- Table 6 - Spearman rank correlation $\rho$ coefficients between the assessments of 
selected components of the organisational climate (A1-A6) and the assessments of employees' performance by the line manager (B5A),

- Table 7 - Spearman rank correlation $\rho$ coefficients between the assessments of selected components of the organisational climate (A1-A6) and selfassesment of employees' performance (B5B),

- Table 8 - Spearman rank correlation $\rho$ coefficients between the assessments of selected components of the organisational climate (A1-A6) and assessments of the degree of convergence of the employee's value with the values promoted in the organisation (B6).

In the study of the correlation between the assessments of selected components of the organisational climate (A1-A6), and the assessments of the degree of achievement of the organisation's goals (B1A) and the assessments of the level of human resources development, shaped by the influence of the supervisor (B2A), no statistically significant differences between groups were found in the resultant correlation coefficients. Therefore, this article skips presentation of the results of these studies as irrelevant to the purpose of this article.

Table 2: Spearman $\rho$ rank correlation coefficient between the assessment of some selected components of the organisational climate (A1-A6) and assessment of delivery on the employee's goals (B1B) in the group of blue collars, white collars without subordinate employees and managers

\begin{tabular}{|c|c|c|c|c|c|c|c|c|c|c|}
\hline \multirow[t]{3}{*}{ No. } & \multirow{3}{*}{$\begin{array}{c}\text { Organisational climate } \\
\text { component }\end{array}$} & \multicolumn{3}{|c|}{ Position } & \multicolumn{6}{|c|}{ Comparison by group } \\
\hline & & \multirow{2}{*}{$\begin{array}{c}\begin{array}{c}\text { Blue } \\
\text { collar }\end{array} \\
1\end{array}$} & \multirow{2}{*}{$\begin{array}{c}\text { White } \\
\text { collar } \\
2\end{array}$} & \multirow{2}{*}{$\begin{array}{c}\begin{array}{c}\text { Manager } \\
\text { s }\end{array} \\
3\end{array}$} & \multicolumn{2}{|c|}{$1-2$} & \multicolumn{2}{|c|}{$1-3$} & \multicolumn{2}{|c|}{$2-3$} \\
\hline & & & & & $\boldsymbol{Z}$ & $p$ & $z$ & $p$ & $z$ & $p$ \\
\hline 1 & 2 & 3 & 4 & 5 & 6 & 7 & 8 & 9 & 10 & 11 \\
\hline 1. & $\begin{array}{l}\text { A1. Equal treatment of } \\
\text { employees }\end{array}$ & $0.242^{* *}$ & $0.315^{* *}$ & $0.309^{* *}$ & -1.24 & 0.186 & -0.95 & 0.254 & 0.09 & 0.397 \\
\hline 2. & $\begin{array}{l}\text { A2A. Trust in information } \\
\text { coming from the line manager }\end{array}$ & $0.377^{* *}$ & $0.437^{* *}$ & $0.387^{* *}$ & -1.12 & 0.212 & -0.15 & 0.394 & 0.81 & 0.287 \\
\hline 3. & $\begin{array}{l}\text { A2B. Trust in information } \\
\text { coming from colleagues }\end{array}$ & $0.279^{* *}$ & $0.303^{* *}$ & $0.118^{*}$ & -0.41 & 0.367 & 2.20 & 0.035 & 2.62 & 0.013 \\
\hline 4. & $\begin{array}{l}\text { A3A. Evaluation of the } \\
\text { remuneration system used in } \\
\text { the organisation }\end{array}$ & $0.242^{* *}$ & $0.254^{* *}$ & $0.269^{* *}$ & -0.20 & 0.391 & -0.38 & 0.371 & -0.22 & 0.390 \\
\hline 5. & $\begin{array}{l}\text { A3B. Evaluation of the } \\
\text { remuneration system used in } \\
\text { the department/team }\end{array}$ & $0.193^{* *}$ & $0.259^{* *}$ & $0.226^{* *}$ & -1.09 & 0.221 & -0.45 & 0.360 & 0.47 & 0.357 \\
\hline 6. & $\begin{array}{l}\text { A4A. Interpersonal relations } \\
\text { in the organisation }\end{array}$ & $0.303^{* *}$ & $0.403^{* *}$ & $0.462^{* *}$ & -1.79 & 0.081 & -2.45 & 0.020 & -0.98 & 0.247 \\
\hline 7. & $\begin{array}{l}\text { A4B. Interpersonal relations } \\
\text { in the department/team }\end{array}$ & $0.311^{* *}$ & $0.362^{* *}$ & $0.333^{* *}$ & -0.90 & 0.266 & -0.32 & 0.379 & 0.44 & 0.361 \\
\hline 8. & $\begin{array}{l}\text { A5A. How effective the } \\
\text { communication system in the } \\
\text { organisation is }\end{array}$ & $0.368^{* *}$ & $0.409^{* *}$ & $0.428^{* *}$ & -0.75 & 0.300 & -0.93 & 0.258 & -0.31 & 0.380 \\
\hline 9. & $\begin{array}{c}\text { A5B. How effective the } \\
\text { communication in a } \\
\text { department/team is }\end{array}$ & $0.346^{* *}$ & $0.412^{* *}$ & $0.328^{* *}$ & -1.20 & 0.193 & 0.27 & 0.385 & 1.31 & 0.169 \\
\hline 10. & $\begin{array}{l}\text { A6. Current engagement in } \\
\text { work in the organisation }\end{array}$ & $0.389^{* *}$ & $0.415^{* *}$ & $0.446^{* *}$ & -0.48 & 0.355 & -0.90 & 0.265 & -0.51 & 0.350 \\
\hline
\end{tabular}

Source: Authors' own analysis based on research results. 
The data presented in Table 2 indicate that a positive correlation between the assessment of the degree of achieving employees' goals (B1B):

- and the level of trust in information coming from the line manager (A2B) was significantly statistically stronger in the group of blue collars and in the group of white collars in non-managerial positions than in the group of colleagues,

- and the assessment of interpersonal relations in the organisation (A4A) had a significantly statistically stronger infuence in the group of managers than in the group of blue collars.

Table 3: Spearman $\rho$ rank correlation coefficient between assessments of some chosen components of the organisational climate (A1-A6) and assessments of the personnel development level resultant from colleagues' influence (B2B) in the group of blue collars, white collars occupying non-managerial positions and managers

\begin{tabular}{|c|c|c|c|c|c|c|c|c|c|c|}
\hline \multirow[t]{3}{*}{ No. } & \multirow{3}{*}{$\begin{array}{c}\text { Organisational climate } \\
\text { component }\end{array}$} & \multicolumn{3}{|c|}{ Position } & \multicolumn{6}{|c|}{ Comparison by group } \\
\hline & & \multirow{2}{*}{$\begin{array}{c}\begin{array}{c}\text { Blue } \\
\text { collar }\end{array} \\
1\end{array}$} & \multirow{2}{*}{$\begin{array}{c}\text { White } \\
\text { collar } \\
2\end{array}$} & \multirow{2}{*}{$\begin{array}{c}\text { Manager } \\
\mathbf{s} \\
3\end{array}$} & \multicolumn{2}{|c|}{$1-2$} & \multicolumn{2}{|c|}{$1-3$} & \multicolumn{2}{|c|}{$2-3$} \\
\hline & & & & & $\boldsymbol{Z}$ & $p$ & $\boldsymbol{Z}$ & $p$ & $\boldsymbol{Z}$ & $p$ \\
\hline 1 & 2 & 3 & 4 & 5 & 6 & 7 & 8 & 9 & 10 & 11 \\
\hline 1. & $\begin{array}{l}\text { A1. Equal treatment of } \\
\text { employees }\end{array}$ & $0.130^{* *}$ & $0.099 *$ & -0.010 & 0.49 & 0.354 & 1.84 & 0.073 & 1.47 & 0.135 \\
\hline 2. & $\begin{array}{l}\text { A2A. Trust in information } \\
\text { coming from the line manager }\end{array}$ & $0.211^{* *}$ & $0.223^{* *}$ & $0.121^{*}$ & -0.20 & 0.391 & 1.21 & 0.191 & 1.42 & 0.146 \\
\hline 3. & $\begin{array}{l}\text { A2B. Trust in information } \\
\text { coming from colleagues }\end{array}$ & $0.361^{* *}$ & $0.328^{* *}$ & $0.174^{* *}$ & 0.58 & 0.336 & 2.65 & 0.012 & 2.22 & 0.034 \\
\hline 4. & $\begin{array}{l}\text { A3A. Evaluation of the } \\
\text { remuneration system used in } \\
\text { the organisation }\end{array}$ & $0.121^{* *}$ & $0.176^{* *}$ & 0.027 & -0.88 & 0.271 & 1.24 & 0.185 & 2.03 & 0.051 \\
\hline 5. & $\begin{array}{l}\text { A3B. Evaluation of the } \\
\text { remuneration system used in } \\
\text { the department/team }\end{array}$ & $0.093^{*}$ & $0.177^{* *}$ & -0.015 & -1.34 & 0.163 & 1.42 & 0.146 & 2.61 & 0.013 \\
\hline 6. & $\begin{array}{l}\text { A4A. Interpersonal relations in } \\
\text { the organisation }\end{array}$ & $0.322^{* *}$ & $0.293^{* *}$ & $0.288^{* *}$ & 0.50 & 0.352 & 0.49 & 0.354 & 0.07 & 0.398 \\
\hline 7. & $\begin{array}{l}\text { A4B. Interpersonal relations in } \\
\text { the department/team }\end{array}$ & $0.329^{* *}$ & $0.318^{* *}$ & $0.258^{* *}$ & 0.19 & 0.392 & 1.02 & 0.238 & 0.88 & 0.271 \\
\hline 8. & $\begin{array}{l}\text { A5A. How effective the } \\
\text { communication system in the } \\
\text { organisation is }\end{array}$ & $0.272^{* *}$ & $0.253^{* *}$ & $0.350^{* *}$ & 0.32 & 0.379 & -1.13 & 0.210 & -1.44 & 0.142 \\
\hline 9. & $\begin{array}{c}\text { A5B. How effective the } \\
\text { communication in a } \\
\text { department/team is }\end{array}$ & $0.378^{* *}$ & $0.315^{* *}$ & $0.307^{* *}$ & 1.12 & 0.213 & 1.05 & 0.229 & 0.12 & 0.396 \\
\hline 10. & $\begin{array}{l}\text { A6. Current engagement in } \\
\text { work in the organisation }\end{array}$ & $0.304^{* *}$ & $0.264^{* *}$ & $0.247^{* *}$ & 0.68 & 0.317 & 0.81 & 0.288 & 0.24 & 0.387 \\
\hline
\end{tabular}

${ }^{*} p<0.05$

$* * p<0,01$

Source: Authors' own analysis based on research results.

The data presented in Table 3 show that a positive correlation between the assessment of the impact of the colleagues' opinion on personnel development level (B2B):

- and the level of trust in the information coming from the line colleagues (A2B) was significantly statistically stronger in the group of blue collars and in the group of white collars in nonmanagerial positions than in the group of managers,

- and the assessment of the remuneration system used in the department or a 
team (A3B) was statistically insignificant in the group of managers.

Table 4: Spearman $\rho$ rank correlation coefficient between the scoring of some chosen components of the organisational climate (A1-A6) and assessment of the employees' capacity to adapt swiftly to changes (B3) in the group of blue collars, white collars occupying non-managerial positions and managers

\begin{tabular}{|c|c|c|c|c|c|c|c|c|c|c|}
\hline \multirow[t]{3}{*}{ No. } & \multirow{3}{*}{$\begin{array}{c}\text { Organisational climate } \\
\text { component }\end{array}$} & \multicolumn{3}{|c|}{ Position } & \multicolumn{6}{|c|}{ Comparison by group } \\
\hline & & \multirow{2}{*}{$\begin{array}{c}\begin{array}{c}\text { Blue } \\
\text { collar }\end{array} \\
1 \\
\end{array}$} & \multirow{2}{*}{$\begin{array}{l}\begin{array}{l}\text { White } \\
\text { collar }\end{array} \\
2\end{array}$} & \multirow{2}{*}{$\begin{array}{c}\begin{array}{c}\text { Manager } \\
\text { s }\end{array} \\
3\end{array}$} & \multicolumn{2}{|c|}{$1-2$} & \multicolumn{2}{|c|}{$1-3$} & \multicolumn{2}{|c|}{$2-3$} \\
\hline & & & & & $z$ & $p$ & $z$ & $p$ & $z$ & $p$ \\
\hline 1 & 2 & 3 & 4 & 5 & 6 & 7 & 8 & 9 & 10 & 11 \\
\hline 1. & $\begin{array}{c}\text { A1. Equal treatment of } \\
\text { employees }\end{array}$ & $0.159^{* *}$ & $0.213^{* *}$ & $0.212^{* *}$ & -0.87 & 0.272 & -0.72 & 0.308 & 0.01 & 0.399 \\
\hline 2. & $\begin{array}{l}\text { A2A. Trust in information } \\
\text { coming from the line } \\
\text { manager }\end{array}$ & $0.375^{* *}$ & $0.378^{* *}$ & $0.230^{* *}$ & -0.05 & 0.398 & 2.10 & 0.044 & 2.20 & 0.035 \\
\hline 3. & $\begin{array}{l}\text { A2B. Trust in information } \\
\text { coming from colleagues }\end{array}$ & $0.286^{* *}$ & $0.215^{* *}$ & 0.116 & 1.18 & 0.198 & 2.33 & 0.027 & 1.37 & 0.156 \\
\hline 4. & $\begin{array}{l}\text { A3A. Evaluation of the } \\
\text { remuneration system used } \\
\text { in the organisation }\end{array}$ & $0.183^{* *}$ & $0.181^{* *}$ & $0.134^{*}$ & 0.03 & 0.399, & 0.66 & 0.321 & 0.65 & 0.323 \\
\hline 5. & $\begin{array}{l}\text { A3B. Evaluation of the } \\
\text { remuneration system used } \\
\text { in the department/team }\end{array}$ & $0.179^{* *}$ & $0.207^{* *}$ & 0.084 & -0.45 & 0.360 & 1.27 & 0.179 & 1.69 & 0.095 \\
\hline 6. & $\begin{array}{l}\text { A4A. Interpersonal } \\
\text { relations in the } \\
\text { organisation }\end{array}$ & $0.339^{* *}$ & $0.317^{* *}$ & $0.350^{* *}$ & 0.38 & 0.370 & -0.16 & 0.394 & -0.50 & 0.352 \\
\hline 7. & $\begin{array}{l}\text { A4B. Interpersonal } \\
\text { relations in the } \\
\text { department/team }\end{array}$ & $0.254^{* *}$ & $0.206^{* *}$ & $0.221^{* *}$ & 0.79 & 0.292 & 0.46 & 0.359 & -0.21 & 0.390 \\
\hline 8. & $\begin{array}{l}\text { A5A. How effective the } \\
\text { communication system in } \\
\text { the organisation is }\end{array}$ & $0.394^{* *}$ & $0.420^{* *}$ & $0.370^{* *}$ & -0.49 & 0.354 & 0.37 & 0.373 & 0.80 & 0.290 \\
\hline 9. & $\begin{array}{l}\text { A5B. How effective the } \\
\text { communication in a } \\
\text { department/team is }\end{array}$ & $0.296^{* *}$ & $0.283^{* *}$ & $0.281^{* *}$ & 0.22 & 0.389 & 0.21 & 0.390 & 0.03 & 0.399 \\
\hline 10. & $\begin{array}{l}\text { A6. Current engagement in } \\
\text { work in the organisation }\end{array}$ & $0.275^{* *}$ & $0.310^{* *}$ & $0.233^{* *}$ & -0.60 & 0.334 & 0.59 & 0.336 & 1.12 & 0.213 \\
\hline
\end{tabular}

Source: Authors' own analysis based on research results.

Table 4 shows that a positive correlation between the assessment of the capacity of an organisation to adapt rapidly to changes (B)

- and the level of trust in information coming from the line manager (A2A) was statistically stronger in the group of blue collars and in the group of white collars in non-managerial positions than in the group of managers,

- and the level of trust in information coming from colleagues (A2B) was statistically insignificant in the group of managers. 
Table 5: Spearman $\rho$ rank correlation coefficient between the scoring of some chosen components of the organisational climate (A1-A6) and the score of employees' capacity to deliver tasks according to the standards prevailing in the organisation (B4) in the group of blue collars and white collars occupying non-managerial positions

\begin{tabular}{|c|c|c|c|c|c|c|c|c|c|c|}
\hline \multirow{3}{*}{$\begin{array}{c}\text { No } \\
\text {. }\end{array}$} & \multirow{3}{*}{$\begin{array}{c}\text { Organisational climate } \\
\text { component }\end{array}$} & \multicolumn{3}{|c|}{ Position } & \multicolumn{6}{|c|}{ Comparison by group } \\
\hline & & \multirow{2}{*}{\begin{tabular}{|c|c|}
$\begin{array}{c}\text { Blue } \\
\text { collar }\end{array}$ \\
1 \\
\end{tabular}} & \multirow{2}{*}{$\begin{array}{c}\text { White } \\
\text { collar } \\
2\end{array}$} & \multirow{2}{*}{$\begin{array}{c}\begin{array}{c}\text { Manag } \\
\text { ers }\end{array} \\
3\end{array}$} & \multicolumn{2}{|c|}{$1-2$} & \multicolumn{2}{|c|}{$1-3$} & \multicolumn{2}{|c|}{$2-3$} \\
\hline & & & & & $Z$ & $p$ & $Z$ & $p$ & $Z$ & $p$ \\
\hline 1 & 2 & 3 & 4 & 5 & 6 & 7 & 8 & 9 & 10 & 11 \\
\hline 1. & $\begin{array}{l}\text { A1. Equal treatment of } \\
\text { employees }\end{array}$ & 0.082 & -0.057 & 0.064 & 2.17 & $\begin{array}{c}0.03 \\
8\end{array}$ & 0.24 & $\begin{array}{c}0.38 \\
8\end{array}$ & $\begin{array}{c}- \\
1.63\end{array}$ & $\begin{array}{c}0.10 \\
5\end{array}$ \\
\hline 2. & $\begin{array}{c}\text { A2A. Trust in } \\
\text { information coming } \\
\text { from the line manager }\end{array}$ & $\begin{array}{c}0.262 \\
* *\end{array}$ & $0.224^{* *}$ & $0.161^{* *}$ & 0.63 & $\begin{array}{c}0.32 \\
7\end{array}$ & 1.39 & $\begin{array}{c}0.15 \\
3\end{array}$ & 0.88 & $\begin{array}{c}0.27 \\
1\end{array}$ \\
\hline 3. & $\begin{array}{c}\text { A2B. Trust in } \\
\text { information coming } \\
\text { from colleagues }\end{array}$ & $\begin{array}{c}0.151 \\
* *\end{array}$ & $0.186^{* *}$ & 0.063 & -0.56 & $\begin{array}{c}0.34 \\
1\end{array}$ & 1.17 & $\begin{array}{c}0.20 \\
2\end{array}$ & 1.68 & $\begin{array}{c}0.09 \\
7\end{array}$ \\
\hline 4. & $\begin{array}{l}\text { A3A. Evaluation of the } \\
\text { remuneration system } \\
\text { used in the organisation }\end{array}$ & 0.086 & -0.012 & 0.096 & 1.53 & $\begin{array}{c}0.12 \\
3\end{array}$ & $\overline{-}$ & $\begin{array}{c}0.39 \\
5\end{array}$ & 1.46 & $\begin{array}{c}0.13 \\
8\end{array}$ \\
\hline 5. & $\begin{array}{c}\text { A3B. Evaluation of the } \\
\text { remuneration system } \\
\text { used in the } \\
\text { department/team }\end{array}$ & 0.084 & -0.009 & 0.107 & 1.46 & $\begin{array}{c}0.13 \\
8\end{array}$ & $\overline{-}$ & $\begin{array}{c}0.38 \\
1\end{array}$ & $\begin{array}{c}- \\
1.57\end{array}$ & $\begin{array}{c}0.11 \\
7\end{array}$ \\
\hline 6. & $\begin{array}{l}\text { A4A. Interpersonal } \\
\text { relations in the } \\
\text { organisation } \\
\end{array}$ & $\begin{array}{c}0.170 \\
* *\end{array}$ & $0.185^{* *}$ & $0.279^{* *}$ & -0.24 & $\begin{array}{c}0.38 \\
7\end{array}$ & $\overline{-}$ & $\begin{array}{c}0.12 \\
9\end{array}$ & $\overline{-}$ & $\begin{array}{c}0.16 \\
3\end{array}$ \\
\hline 7. & $\begin{array}{l}\text { A4B. Interpersonal } \\
\text { relations in the } \\
\text { department/team }\end{array}$ & $\begin{array}{c}0.166 \\
* *\end{array}$ & $0.209^{* *}$ & $0.260^{* *}$ & -0.70 & $\begin{array}{c}0.31 \\
3\end{array}$ & 1.29, & $\begin{array}{c}0.17 \\
3\end{array}$ & $\overline{-}-$ & $\begin{array}{c}0.30 \\
6\end{array}$ \\
\hline 8. & $\begin{array}{l}\text { A5A. How effective the } \\
\text { communication system } \\
\text { in the organisation is }\end{array}$ & $\begin{array}{c}0.256 \\
* *\end{array}$ & $0.215^{* *}$ & $0.222^{* *}$ & 0.68 & $\begin{array}{c}0.31 \\
7\end{array}$ & 0.47 & $\begin{array}{c}0.35 \\
7\end{array}$ & $\overline{-}$ & $\begin{array}{c}0.39 \\
7\end{array}$ \\
\hline 9. & $\begin{array}{l}\text { A5B. How effective the } \\
\text { communication in a } \\
\text { department/team is }\end{array}$ & $\begin{array}{c}0.293 \\
* *\end{array}$ & $0.255^{* *}$ & $0.253^{* *}$ & 0.64 & $\begin{array}{c}0.32 \\
5\end{array}$ & 0.57 & $\begin{array}{c}0.34 \\
0\end{array}$ & 0.03 & $\begin{array}{c}0.39 \\
9\end{array}$ \\
\hline 10. & $\begin{array}{l}\text { A6. Current engagement } \\
\text { in work in the } \\
\text { organisation }\end{array}$ & $\begin{array}{l}0.360 \\
* *\end{array}$ & $0.315^{* *}$ & $0.323^{* *}$ & 0.79 & $\begin{array}{c}0.29 \\
1\end{array}$ & 0.55 & $\begin{array}{c}0.34 \\
3\end{array}$ & $-\overline{1}$ & $\begin{array}{c}0.39 \\
6\end{array}$ \\
\hline
\end{tabular}

It was found that the correlations between the scoring given for the degree of the work compliance with the rules and the scoring for employees' treatment by their line managers were statistically different in terms of their value; however, there were not statistically different in any of these groups. 
Table 6: Spearman $\rho$ rank correlation coefficient between the scoring of some chosen components of the organisational climate (A1-A6) and the score of employees' capacity to deliver tasks according to the line manager (B5A) in the group of blue collars, white collars occupying non-managerial positions and managers

\begin{tabular}{|c|c|c|c|c|c|c|c|c|c|c|}
\hline \multirow{3}{*}{ No } & \multirow{3}{*}{$\begin{array}{c}\text { Organisational climate } \\
\text { component }\end{array}$} & \multicolumn{3}{|c|}{ Position } & \multicolumn{6}{|c|}{ Comparison by group } \\
\hline & & \multirow{2}{*}{$\begin{array}{c}\begin{array}{c}\text { Blue } \\
\text { collar }\end{array} \\
1 \\
\end{array}$} & \multirow{2}{*}{$\begin{array}{c}\text { White } \\
\text { collar } \\
2\end{array}$} & \multirow{2}{*}{$\begin{array}{c}\begin{array}{c}\text { Manag } \\
\text { ers }\end{array} \\
3\end{array}$} & \multicolumn{2}{|c|}{$1-2$} & \multicolumn{2}{|c|}{$1-3$} & \multicolumn{2}{|c|}{$2-3$} \\
\hline & & & & & $Z$ & $p$ & $Z$ & $p$ & $Z$ & $p$ \\
\hline 1 & 2 & 3 & 4 & 5 & 6 & 7 & 8 & 9 & 10 & 11 \\
\hline 1. & $\begin{array}{l}\text { A1. Equal treatment of } \\
\text { employees }\end{array}$ & $\begin{array}{c}0.208 \\
* *\end{array}$ & $0.265^{* *}$ & $0.184^{* *}$ & -0.94 & $\begin{array}{c}0.25 \\
6 \\
\end{array}$ & 0.33 & $\begin{array}{c}0.37 \\
8 \\
\end{array}$ & 1.15 & $\begin{array}{c}0.20 \\
6 \\
\end{array}$ \\
\hline 2. & $\begin{array}{c}\text { A2A. Trust in } \\
\text { information coming } \\
\text { from the line manager }\end{array}$ & $\begin{array}{c}0.266 \\
* *\end{array}$ & $0.345^{* *}$ & $0.270^{* *}$ & -1.36 & $\begin{array}{c}0.15 \\
8\end{array}$ & 0.06 & $\begin{array}{c}0.39 \\
8\end{array}$ & 1.12 & $\begin{array}{c}0.21 \\
4\end{array}$ \\
\hline 3. & $\begin{array}{c}\text { A2B. Trust in } \\
\text { information coming } \\
\text { from colleagues }\end{array}$ & $\begin{array}{c}0.144 \\
* *\end{array}$ & $0.279^{* *}$ & 0.107 & -2.21 & $\begin{array}{c}0.03 \\
5\end{array}$ & 0.49 & $\begin{array}{c}0.35 \\
3\end{array}$ & 2.41 & $\begin{array}{c}0.02 \\
2\end{array}$ \\
\hline 4. & $\begin{array}{l}\text { A3A. Evaluation of the } \\
\text { remuneration system } \\
\text { used in the organisation }\end{array}$ & $\begin{array}{l}0.156 \\
* *\end{array}$ & $0.173^{* *}$ & $0.276^{* *}$ & -0.27 & $\begin{array}{c}0.38 \\
4\end{array}$ & $-\overline{6}$ & $\begin{array}{c}0.10 \\
2\end{array}$ & - & $\begin{array}{c}0.13 \\
7\end{array}$ \\
\hline 5. & $\begin{array}{c}\text { A3B. Evaluation of the } \\
\text { remuneration system } \\
\text { used in the } \\
\text { department/team } \\
\end{array}$ & $\begin{array}{l}0.112 \\
*\end{array}$ & $0.216^{* *}$ & $0.228^{* *}$ & -1.67 & $\begin{array}{c}0.09 \\
9\end{array}$ & $\begin{array}{c}- \\
1.57\end{array}$ & $\begin{array}{c}0.11 \\
7\end{array}$ & $\overline{-}$ & $\begin{array}{c}0.39 \\
3\end{array}$ \\
\hline 6. & $\begin{array}{l}\text { A4A. Interpersonal } \\
\text { relations in the } \\
\text { organisation }\end{array}$ & $\begin{array}{c}0.232 \\
* *\end{array}$ & $0.299 * *$ & $0.294^{* *}$ & -1.13 & $\begin{array}{c}0.21 \\
2\end{array}$ & 0.87 & $\begin{array}{c}0.27 \\
3\end{array}$ & 0.07 & $\begin{array}{c}0.39 \\
8\end{array}$ \\
\hline 7. & $\begin{array}{l}\text { A4B. Interpersonal } \\
\text { relations in the } \\
\text { department/team }\end{array}$ & $\begin{array}{l}0.222 \\
* *\end{array}$ & $0.374^{* *}$ & $0.277^{* *}$ & -2.61 & $\begin{array}{c}0.01 \\
3\end{array}$ & $\begin{array}{c}- \\
0.77\end{array}$ & $\begin{array}{c}0.29 \\
7\end{array}$ & 1.46 & $\begin{array}{c}0.13 \\
7\end{array}$ \\
\hline 8. & $\begin{array}{l}\text { A5A. How effective the } \\
\text { communication system } \\
\text { in the organisation is }\end{array}$ & $\begin{array}{c}0.164 \\
* *\end{array}$ & $0.254^{* *}$ & $0.192^{* *}$ & -1.47 & $\begin{array}{c}0.13 \\
5\end{array}$ & $\begin{array}{c}- \\
0.38\end{array}$ & $\begin{array}{c}0.37 \\
1\end{array}$ & 0.88 & $\begin{array}{c}0.27 \\
1\end{array}$ \\
\hline 9. & $\begin{array}{l}\text { A5B. How effective the } \\
\text { communication in a } \\
\text { department/team is }\end{array}$ & $\begin{array}{c}0.250 \\
* *\end{array}$ & $0.344^{* *}$ & $0.233^{* *}$ & -1.61 & $\begin{array}{c}0.10 \\
9\end{array}$ & 0.24 & $\begin{array}{c}0.38 \\
8\end{array}$ & 1.63 & $\begin{array}{c}0.10 \\
5\end{array}$ \\
\hline 10. & $\begin{array}{l}\text { A6. Current engagement } \\
\text { in work in the } \\
\text { organisation }\end{array}$ & $\begin{array}{c}0.292 \\
* *\end{array}$ & $0.308^{* *}$ & $0.396^{* *}$ & -0.27 & $\begin{array}{c}0.38 \\
4\end{array}$ & $\begin{array}{c}- \\
1.55\end{array}$ & $\begin{array}{c}0.12 \\
1\end{array}$ & $\begin{array}{c}- \\
1.35\end{array}$ & $\begin{array}{c}0.16 \\
0\end{array}$ \\
\hline
\end{tabular}

Source: Authors' own analysis based on research results.

According to Table 6, a positive correlation between the assessment of employees' individual capacity made by their line manager (B5A):

- and the level of trust in the information coming from colleagues (A2B) was the strongest in the group of white- collar workers at non- managerial positions, weaker in the group of blue- collar employees, statistically insignificant in the managers' group,

- and the assessment of interpersonal relations in the department or a team (A4B) was stronger in a group of whitecollar workers in non-managerial positions than in the group of bluecollar workers. 
Table 7: Spearman $\rho$ rank correlation coefficient between the scoring of some chosen components of the organisational climate (A1-A6) and assessment of the employees' capacity to deliver tasks according to the employee concerned (B5B) in the group of blue collars, white collars occupying non-managerial positions and managers

\begin{tabular}{|c|c|c|c|c|c|c|c|c|c|c|}
\hline \multirow{3}{*}{$\begin{array}{c}\text { No } \\
\text {. }\end{array}$} & \multirow{3}{*}{$\begin{array}{l}\text { Organisational climate } \\
\text { component }\end{array}$} & \multicolumn{3}{|c|}{ Position } & \multicolumn{6}{|c|}{ Comparison by group } \\
\hline & & \multirow{2}{*}{\begin{tabular}{|c|}
$\begin{array}{c}\text { Blue } \\
\text { collar }\end{array}$ \\
1 \\
\end{tabular}} & \multirow{2}{*}{$\begin{array}{c}\text { White } \\
\text { collar } \\
2\end{array}$} & \multirow{2}{*}{$\begin{array}{c}\begin{array}{c}\text { Manag } \\
\text { ers }\end{array} \\
3\end{array}$} & \multicolumn{2}{|c|}{$1-2$} & \multicolumn{2}{|c|}{$1-3$} & \multicolumn{2}{|c|}{$2-3$} \\
\hline & & & & & $Z$ & $p$ & $Z$ & $p$ & $Z$ & $p$ \\
\hline 1 & 2 & 3 & 4 & 5 & 6 & 7 & 8 & 9 & 10 & 11 \\
\hline 1. & $\begin{array}{l}\text { A1. Equal treatment of } \\
\text { employees }\end{array}$ & $\begin{array}{c}0.116 \\
*\end{array}$ & -0.016 & 0.066 & 2.07 & $\begin{array}{c}0.04 \\
7\end{array}$ & 0.66 & $\begin{array}{c}0.32 \\
1\end{array}$ & $\begin{array}{c}- \\
1.11\end{array}$ & $\begin{array}{c}0.21 \\
7\end{array}$ \\
\hline 2. & $\begin{array}{c}\text { A2A. Trust in } \\
\text { information coming } \\
\text { from the line manager }\end{array}$ & $\begin{array}{c}0.160 \\
* *\end{array}$ & 0.071 & $0.142^{*}$ & 1.41 & $\begin{array}{c}0.14 \\
8\end{array}$ & 0.24 & $\begin{array}{c}0.38 \\
8\end{array}$ & $\begin{array}{c}- \\
0.97\end{array}$ & $\begin{array}{c}0.25 \\
0\end{array}$ \\
\hline 3. & $\begin{array}{c}\text { A2B. Trust in } \\
\text { information coming } \\
\text { from colleagues }\end{array}$ & $\begin{array}{l}0.120 \\
*\end{array}$ & $0.124^{* *}$ & 0.115 & -0.06 & $\begin{array}{c}0.39 \\
8\end{array}$ & 0.07 & $\begin{array}{c}0.39 \\
8\end{array}$ & 0.12 & $\begin{array}{c}0.39 \\
6\end{array}$ \\
\hline 4. & $\begin{array}{l}\text { A3A. Evaluation of the } \\
\text { remuneration system } \\
\text { used in the organisation }\end{array}$ & 0.005 & -0.023 & 0.074 & 0.44 & $\begin{array}{c}0.36 \\
3\end{array}$ & $\overline{-}$ & $\begin{array}{c}0.26 \\
5\end{array}$ & $\overline{-}$ & $\begin{array}{c}0.17 \\
0\end{array}$ \\
\hline 5. & $\begin{array}{c}\text { A3B. Evaluation of the } \\
\text { remuneration system } \\
\text { used in the } \\
\text { department/team }\end{array}$ & -0.004 & -0.007 & 0.004 & 0.05 & $\begin{array}{c}0.39 \\
9\end{array}$ & 0.10 & $\begin{array}{c}0.39 \\
7\end{array}$ & $\overline{-}$ & $\begin{array}{c}0.39 \\
5\end{array}$ \\
\hline 6. & $\begin{array}{l}\text { A4A. Interpersonal } \\
\text { relations in the } \\
\text { organisation } \\
\end{array}$ & $\begin{array}{c}0.138 \\
* *\end{array}$ & 0.064 & $0.171^{* *}$ & 1.17 & $\begin{array}{c}0.20 \\
2\end{array}$ & $0 . \overline{4}$ & $\begin{array}{c}0.36 \\
2\end{array}$ & 1.46 & $\begin{array}{c}0.13 \\
7\end{array}$ \\
\hline 7. & $\begin{array}{l}\text { A4B. Interpersonal } \\
\text { relations in the } \\
\text { department/team }\end{array}$ & $\begin{array}{l}0.100 \\
*\end{array}$ & $0.101^{*}$ & $0.232^{* *}$ & -0.02 & $\begin{array}{c}0.39 \\
9\end{array}$ & $\overline{-}$ & $\begin{array}{c}0.08 \\
2\end{array}$ & $\overline{-}$ & $\begin{array}{c}0.07 \\
7\end{array}$ \\
\hline 8. & $\begin{array}{l}\text { A5A. How effective the } \\
\text { communication system } \\
\text { in the organisation is }\end{array}$ & $\begin{array}{c}0.142 \\
* *\end{array}$ & 0.067 & $0.150^{*}$ & 1.18 & $\begin{array}{c}0.19 \\
8\end{array}$ & $\overline{-}$ & $\begin{array}{c}0.39 \\
7\end{array}$ & $\overline{-}$ & $\begin{array}{c}0.21 \\
0\end{array}$ \\
\hline 9. & $\begin{array}{l}\text { A5B. How effective the } \\
\text { communication in a } \\
\text { department/team is }\end{array}$ & $\begin{array}{c}0.140 \\
* *\end{array}$ & $0.138^{* *}$ & $0.227^{* *}$ & 0.03 & $\begin{array}{c}0.39 \\
9\end{array}$ & $\overline{-}$ & $\begin{array}{c}0.19 \\
9\end{array}$ & $\begin{array}{c}- \\
1.24\end{array}$ & $\begin{array}{c}0.18 \\
5\end{array}$ \\
\hline 10. & $\begin{array}{l}\text { A6. Current engagement } \\
\text { in work in the } \\
\text { organisation }\end{array}$ & $\begin{array}{c}0.293 \\
* *\end{array}$ & $0.402^{* *}$ & $0.418^{* *}$ & -1.94 & $\begin{array}{c}0.06 \\
1\end{array}$ & $\begin{array}{c}- \\
1.88\end{array}$ & $\begin{array}{c}0.06 \\
8\end{array}$ & $\begin{array}{c}- \\
0.26\end{array}$ & $\begin{array}{c}0.38 \\
6\end{array}$ \\
\hline
\end{tabular}

Table 7 shows that the positive correlation between the self-assessment of individual performance made by the employee (B5B) and the assessment of equal treatment of employees by the line manager (A1) was statistically significant only in the group of people employed in blue-collar positions. 
Table 8: Spearman $\rho$ rank correlation coefficient between the assessment of selected components of the organisational climate (A1-A6) and assessment of the degree of convergence between the employee's values and the values promoted in the organisation (B6) in the group of blue collars, white collars occupying non-managerial positions and managers

\begin{tabular}{|c|c|c|c|c|c|c|c|c|c|c|}
\hline \multirow{3}{*}{ No } & \multirow{3}{*}{$\begin{array}{l}\text { Organisational climate } \\
\text { component }\end{array}$} & \multicolumn{3}{|c|}{ Position } & \multicolumn{6}{|c|}{ Comparison by group } \\
\hline & & \multirow{2}{*}{$\begin{array}{c}\begin{array}{c}\text { Blue } \\
\text { collar }\end{array} \\
1\end{array}$} & \multirow{2}{*}{$\begin{array}{c}\text { White } \\
\text { collar } \\
2\end{array}$} & \multirow{2}{*}{$\begin{array}{c}\text { Manag } \\
\text { ers }\end{array}$} & \multicolumn{2}{|c|}{$1-2$} & \multicolumn{2}{|c|}{$1-3$} & \multicolumn{2}{|c|}{$2-3$} \\
\hline & & & & & $Z$ & $p$ & $\boldsymbol{Z}$ & $p$ & $z$ & $p$ \\
\hline 1 & 2 & 3 & 4 & 5 & 6 & 7 & 8, & 9 & 10 & 11 \\
\hline 1. & $\begin{array}{c}\text { A1. Equal treatment of } \\
\text { employees }\end{array}$ & $\begin{array}{c}0.175 \\
* * \\
\end{array}$ & $0.262^{* *}$ & $0.184^{* *}$ & -1.43 & $\begin{array}{c}0.14 \\
4 \\
\end{array}$ & $\overline{-}$ & $\begin{array}{c}0.39 \\
6 \\
\end{array}$ & 1.11 & $\begin{array}{c}0.21 \\
6\end{array}$ \\
\hline 2. & $\begin{array}{c}\text { A2A. Trust in } \\
\text { information coming } \\
\text { from the line manager }\end{array}$ & $\begin{array}{c}0.283 \\
* *\end{array}$ & $0.349^{* *}$ & $0.373^{* *}$ & -1.15 & $\begin{array}{c}0.20 \\
7\end{array}$ & $\overline{-}$ & $\begin{array}{c}0.16 \\
6\end{array}$ & $-\overline{37}$ & $\begin{array}{c}0.37 \\
2\end{array}$ \\
\hline 3. & $\begin{array}{c}\text { A2B. Trust in } \\
\text { information coming } \\
\text { from colleagues } \\
\end{array}$ & $\begin{array}{l}0.299 \\
* *\end{array}$ & $0.255^{* *}$ & $0.165^{* *}$ & 0.74 & $\begin{array}{l}0.30 \\
2,\end{array}$ & 1.86, & $\begin{array}{c}0.07 \\
1,\end{array}$ & 1.27, & $\begin{array}{c}0.17 \\
8,\end{array}$ \\
\hline 4. & $\begin{array}{l}\text { A3A. Evaluation of the } \\
\text { remuneration system } \\
\text { used in the organisation }\end{array}$ & $\begin{array}{c}0.138 \\
* *\end{array}$ & $0.265^{* *}$ & $0.196^{* *}$ & -2.07 & $\begin{array}{c}0.04 \\
7\end{array}$ & $\begin{array}{c}- \\
0.78\end{array}$ & $\begin{array}{c}0.29 \\
4\end{array}$ & 0.98, & $\begin{array}{c}0.24 \\
6\end{array}$ \\
\hline 5. & $\begin{array}{c}\text { A3B. Evaluation of the } \\
\text { remuneration system } \\
\text { used in the } \\
\text { department/team }\end{array}$ & $\begin{array}{c}0.125 \\
* *\end{array}$ & $0.231^{* *}$ & $0.178^{* *}$ & -1.71 & $\begin{array}{l}0.09 \\
2,\end{array}$ & $\begin{array}{c}- \\
0.71\end{array}$ & $\begin{array}{c}0.31 \\
0\end{array}$ & 0.74, & $\begin{array}{c}0.30 \\
2,\end{array}$ \\
\hline 6. & $\begin{array}{l}\text { A4A. Interpersonal } \\
\text { relations in the } \\
\text { organisation } \\
\end{array}$ & $\begin{array}{c}0.379 \\
* *\end{array}$ & $0.336^{* *}$ & $0.326^{* *}$ & 0.77, & $\begin{array}{l}0.29 \\
7\end{array}$ & 0.79, & $\begin{array}{c}0.29 \\
1,\end{array}$ & 0.15, & $\begin{array}{c}0.39 \\
4\end{array}$ \\
\hline 7. & $\begin{array}{l}\text { A4B. Interpersonal } \\
\text { relations in the } \\
\text { department/team } \\
\end{array}$ & $\begin{array}{c}0.260 \\
* *\end{array}$ & $0.265^{* *}$ & $0.177^{* *}$ & -0.08 & $\begin{array}{l}0.39 \\
8\end{array}$ & 1.14, & $\begin{array}{l}0.20 \\
8\end{array}$ & 1.25, & $\begin{array}{c}0.18 \\
3\end{array}$ \\
\hline 8. & $\begin{array}{l}\text { A5A. How effective the } \\
\text { communication system } \\
\text { in the organisation is }\end{array}$ & $\begin{array}{l}0.434 \\
* *\end{array}$ & $0.376^{* *}$ & $0.366^{* *}$ & 1.08 & $\begin{array}{l}0.22 \\
2,\end{array}$ & 1.06, & $\begin{array}{c}0.22 \\
7,\end{array}$ & 0.16, & $\begin{array}{c}0.39 \\
4\end{array}$ \\
\hline 9. & $\begin{array}{c}\text { A5B. How effective the } \\
\text { communication in a } \\
\text { department/team is }\end{array}$ & $\begin{array}{c}0.332 \\
* *\end{array}$ & $0.292^{* *}$ & $0.208^{* *}$ & 0.69, & $\begin{array}{c}0.31 \\
4\end{array}$ & 1.75, & $\begin{array}{c}0.08 \\
6,\end{array}$ & 1.21, & $\begin{array}{c}0.19 \\
2\end{array}$ \\
\hline 10. & $\begin{array}{l}\text { A6. Current engagement } \\
\text { in work in the } \\
\text { organisation }\end{array}$ & $\begin{array}{c}0.278 \\
* *\end{array}$ & $0.313^{* *}$ & $0.303^{* *}$ & -0.60 & $\begin{array}{c}0.33 \\
3\end{array}$ & $\begin{array}{c}- \\
0.36\end{array}$ & $\begin{array}{c}0.37 \\
4,\end{array}$ & 0.15 , & $\begin{array}{c}0.39 \\
5\end{array}$ \\
\hline
\end{tabular}

Source: Authors' own analysis based on research results.

Table 8 shows that the positive correlation between the assessments of the degree of convergence of the employee value with the bonus values in the organisation (B6) and the assessment of the remuneration system used in the organisation (A3A) was stronger in the group of people employed in non-manual positions without subordinate employees than in the group of employees' worker positions. 


\section{Research conclusions and recommendations for practice}

The aim of the research, the results of which are presented in this article, was to search for an answer to the question: does the type of job (blue collar, non-worker without subordinate employees, managerial position) determine the structure of the pro-efficiency model of the organisational climate. On the basis of the collected factual material, the following conclusions can be drawn:

1) All the components of the organisational climate specified in the model (A1-A6) influenced the criteria of organisational effectiveness (B1B6), although not all the relationships turned out to be statistically significant (this article presents the results of the research concerning only statistically significant relationships).

2) The components of the organisational climate and the criteria of organisational effectiveness for all three groups of respondents partially overlapped. Note that: a) in case of the blue-collar
employees:

- the level of trust in the
information received from the
supervisor (A2A) had a
significant impact on the
assessment of the degree of the
organisation's ability to quickly
adapt (adapt) to changes (B3),
- the level of trust in the
information received from
colleagues (A2B) had a
significant impact on the degree
of achievement of the
employee's own goals (B1B)
and the assessment of the
degree of impact of colleagues
on the level of human resources
development (B2B) and the
assessment of individual
employee performance by the
supervisor (B5A),

b) in case of employees occupying non-manual positions without subordinate employees:

- the level of trust in the information received from the supervisor (A2A) had a significant impact on the assessment of the degree of the organisation's ability to adapt quickly to changes (B3),

- the level of trust in the information received from colleagues (A2B) had a significant impact on the degree of achievement of the employee's own goals (B1B) and the assessment of the degree of impact of colleagues on the level of human resources development (B2B) and the assessment of individual employee's performance by the supervisor (B5A),

- the remuneration system used in the organisation (A3) significantly influenced the assessment of the level of convergence of the employee's values with the values awarded in the organisation (B6) and this distinguishes this group of employees from employees holding blue-collar positions

c) in case of employees holding managerial positions:

- assessment of equal treatment of employees (A1) influenced the self-assessment of individual employee performance (B5B),

- interpersonal relations in the organisation (A4) affected predominantly the degree of achievement of their own goals (B1B).

3) Employees from all three groups indicated the degree of achievement of the employee's own goals (B1B) as a significant criterion of organisational effectiveness, however, according to employees in the following positions:

a) workers and non-workers without subordinate employees - this assessment was 
influenced by the level of trust in the information received from co-workers (A2B),

b) employees in managerial positions - this assessment was influenced by the assessment of interpersonal relations in the organisation (A4A).

4) Employees occupying managerial positions indicated as the only group of employees the importance of such a component of the organisational climate as the assessment of equal treatment by the line manager (A1). This component influenced such a criterion of organisational effectiveness as the self-assessment of the employee's own performance (B5B), which was also important only for this group of respondents (it was not indicated in any of the other two groups).

5) For employees holding blue-collar and non-manual worker positions without subordinate employees, such organisational effectiveness criterion as:

a) self-assessment of their own performance (B5B) does not play a significant role,

b) the assessment of their performance made by their line managers (B5A) is statistically significant, and this parameter is influenced in both cases by such a component of the organisational climate as the level of trust in the information provided by colleagues (B2B), but this impact is stronger in the case of workers in nonmanual positions without subordinate employees, rather than blue-collar workers.

6) Only employees occupying nonworker positions without subordinate employees indicated that the criterion of organisational effectiveness as statistically significant, such as the convergence of the employee's value with the premium values in the organisation (B6) - they are influenced by the assessment of the current level of reward used in the organisation (A3A), i.e. Mentionet above organisational climate component was ignored by the other two groups of respondents.

The knowledge of the existence of a wide range of organisational climate components and the ability to identify those of particular importance to employees in a specific organisation is a key measure of the professionalism level of a modern manager and one of the leading challenges facing them. The aim of this article was to draw attention to the different preferences related to the modelling of the structure of the proeffective organisational climate, taking into account the type of workstation.

For employees occupying blue-collar positions, the most important component turned out to be the level of trust in the information provided to them by their line managers (it affects the organisation's ability to quickly adapt to changes). It shapes the assessment of the employee's individual performance made by his/her supervisor, as well as the degree of achievement of the employee's own goals and the scope of influence of colleagues on the level of development of this employee. For employees occupying non-manual positions without subordinate employees, apart from trust, the essence of which has been discussed above, the evaluation of the reward system used in the organisation is equally important, as it affects the degree of convergence of the values professed by the employee with the values awarded in the organisation. For managers, however, the most important are completely different components of the organisational climate. The group increases the weight of such parameters as:

- equal treatment of employees by their line managers - which affects the self-assessment of their own performances,

- interpersonal relations in the organisation - which affects the degree of achievement of their own goals.

The role and responsibility of managers in emphasizing the importance of appropriate 
elements of the pro-efficiency model of the organisational climate is significant. They should bear in mind the fact that the psychological dimension of work may be just as important as its economic function, which identifies work as a source of income and emphasizes the achievement of a specific financial result.

Identifying the components of the organisational climate in a particular organisation and their implementation may indicate that the manager has acquired extremely valuable skills

\section{References}

- Aarons, GA. and Sawitzky, AC. (2006), 'Organizational Culture and Climate and Mental Health Provider Attitudes Toward Evidence-Based Practice', Psychological Services, 1 (3), 61-72.

- Abendroth, AK. and Den Dulk, L. (2011), 'Support for the work-life balance in Europe: the impact of state, workplace and family support on work-life balance satisfaction', Work, Employment and Society, 2, 234-256.

- Altaf, A. (2011), 'The impact of organizational culture on organizational effectiveness: implication of Hofstede Cultural Model as organizational effectiveness model', The International Journal of Interdisciplinary Social Sciences, 6 (1), 161-162.

- Avgar, AC., Kolins-Givan, R. and Liu, M. (2011), 'A balancing act: work-life balance and multiple stakeholder outcomes in hospitals', British Journal of Industrial Relations, 4, 717-741.

- Aybas, M. and Cevat Acar, A. (2017), 'The Effect of Human Resource Management Practices on Em ployees' Work Engagement and the Mediating and Moderating Role of Positive Psycholog ical Capital', International Review of Management and Marketing, 7 (1), 363-372.
- Badura, B. (2016), 'Auf die Bindung kommt es an - Organisationskultur und Gesundheit', Bewährungshilfe, 63 (1), 15-18.

- Baruk, AI. (2014), 'Poziom zadowolenia pracowników w kontekście relacyjnych aspektów klimatu organizacyjnego', Zeszyty Naukowe Politechniki Śląskiej: seria Organizacja i Zarządzanie, 73, 11-21.

- Bielski, M. (2002), 'Podstawy teorii organizacji i zarządzania, C.H.Beck, Warszawa.

- $\quad$ Blaik, P. (2015), 'Efektywność logistyki. Aspekt systemowy i zarządczy', PWE, Warszawa.

- $\quad$ Bratnicki, M. and Wyciślak, M. (1980), 'Klimat organizacyjny: pojęcie, mierzenie, badanie i diagnoza', Prakseologia, 4 (76), 85-103.

- $\quad$ Cameron, KS. (1986), 'Effectiveness as Paradox: Consensus and Conflict in Conceptions of Organizational Effectiveness', Management Science, 32 (5), 539-553.

- Dabić, M., Lažnjak, J., Smallbone, D. and Švarc, J. (2018), 'Intellectual capital,organisational climate, innovation culture, and SME performance: Evidence from Croatia', Journal of Small Business and Enterprise Development, [Online], [Retrieved October 15, 2018], https://doi.org/10.1108/JSBED-042018-0117.

- Davidson, MCG., Manning, M.L., Timo, N. and Ryder PA. (2001), The dimensions of organizational climate in four and five star Australian hotels', Journal of Hospitality \& Tourism Research, 25 (4), 444-461.

- Dessler, G. and Turner, A. (1992), Human Resource Management in Canada, Prentice-Hall Canada Inc., Scarborough. 
- Forehand, GA. and Gilmer, B. (1964), 'Environmental variation in studies of organizational behavior', Psychological Bulletin, 62, 361-382.

- Goodman, PS. and Pennings, JM. (1977), New perspectives on organizational effectiveness, JosseyBass San Francisco.

- Gregopoulos, B. (1965), 'Normative structure variables and organizational behavior', Human Relations, 18, 115170.

- Harrington, HJ. and Voehl, F. (2015), 'Cultural Change Management', International Journal of Innovation Science, 7 (1), 55-74.

- Hulkko Nyman, K., Sarti, D., Hakonen, A. and Sweins, C. (2014), 'Total rewards perceptions and work engagement in elder care organizations: Findings from Finland and Italy', International Studies of Management \& Organization, 42 (1), 24-49, [Online], [Retrieved October 15, 2018], https://doi.org/10.2753/ IM00020-8825420102.

- Jacobs, S., Renard, M. and Snelgar, RJ. (2014), 'Intrinsic rewards and work engagement in the South African retail industry', South African Journal of Industrial Psychology, 40 (2), 1-13, [Online], [Retrieved October 15, 2018], https://sajip.co.za/index.php/sajip/art icle/view/1195/1652.

- Konkladar, VG. (2010), Organization Effectiveness and Change Management, Prentice Hall India Learning Private Ltd., Delhi.

- Kundu, K. (2007), 'Development of the conceptual framework of organizational climate', Vidyasagar University Journal of Commerce, 12, 99108.

- Lawless, DJ. (1972), Effective Management. Social Psychological Approach, Wyd. Prentice-Hall, Englewood Cliffs, New Jersey.
- Lewin, AY. and Minton, JW. (1986), 'Determining Organizational Effectiveness: Another Look and an Agenda for Research', Management Science, 32 (5), 514-538.

- $\quad$ Łochnicka, D. (2016), Przedsiębiorczość pracownicza i jej wpływ na efektywność organizacji, Wyd. Uniwersytetu Łódzkiego, Łódź.

- McDonald, P., Townsend, K. and Wharton A. (2013), 'The legitimation and reproduction of discourse-practice gaps in work-life balance', Personnel Review, 1-2, 205-222.

- Price, L. (2008), 'The Study of Organizational Effectiveness', Sociological Quarterly, 13 (1), 3-15.

- Pyszka, A. (2015), 'Istota efektywności. Definicje i wymiary', Studia Ekonomiczne. Zeszyty Naukowe Uniwersytetu Ekonomicznego w Katowicach, 230, 13-25.

- Von Rosenstiel, L. and Bögel, F. (1992), Betriebsklima geht jeden an. Bayerischer Staatsministerium für Arbeit, Familie und Sozialordnung, München.

- Skrzypek, E. (2007), 'Efektywność ekonomiczna jako ważny czynnik sukcesu organizacji', Efektywność konceptualizacja i uwarunkowania, Dudycz, T., Osbert-Pociecha, G. and Brycz, B. (ed.), Prace Naukowe Uniwersytetu Ekonomicznego we Wrocławiu, 262, 313-325.

- Steers, RM. (1975), 'Problems in the Measurement of Organizational Effectiveness', Administrative Science Quarterly, 20 (4), 546-558.

- Wajszczak, E. (2000), Kształtowanie klimatu organizacyjnego w przedsiębiorstwie, Oficyna Wydawnicza Ośrodka Postępu Organizacyjnego Sp. z o.o., Bydgoszcz. 
- Wudarzewski, G. (2016), 'Początki zainteresowań problematyką klimatu organizacyjnego w polskiej literaturze naukowej', Zeszyty Naukowe Wyższej Szkoły Bankowej we Wrocławiu, 16 I (1), 55-71.

- Wudarzewski, G. (2013), 'Interpretacja i znaczenie metafory „klimat organizacyjny” w zarządzaniu', Zeszyty Naukowe Wyższej Szkoły Bankowej we Wrocławiu, 6 (38), 203-219.

- Wudarzewski, G. (2013), 'Wymiary i składniki klimatu organizacyjnego w świetle badań literaturowych', Zeszyty Naukowe Wyższej Szkoły Bankowej we Wrocławiu, 1 (33), 59-78.
- Yongxing, G., Hongfei, D., Baoguo, X. and Lei, M. (2017), 'Work engagement and job performance: the moderating role of perceived organizational support', Anales de Psicología, 33 (3), 708-713, [Online], [Retrieved October 15 , 2018], http://dx.doi.org/10.6018/analesps.33 .3 .238571 .

- Ziębicki, B. (2014), Efektywność organizacyjna podmiotów sektora publicznego, Wydawnictwo Uniwersytetu Ekonomicznego w Krakowie, Kraków. 